\title{
The Application Research of Nominal Accounts on the New Agriculture Insurance Based on the All-Inclusive Society Mode
}

\author{
Xiaowen Gong \\ College of Management \\ Shanghai University of Engineering Science \\ Shanghai, China \\ xiaowen_salen@163.com
}

\author{
Xinde Chen \\ College of Management \\ Shanghai University of Engineering Science \\ Shanghai, China \\ xindechen@163.com
}

\begin{abstract}
The social security of China is going forward to all-inclusive society mode, establishing a pension system compound with social account and personal account. But the "one-size-fits-all" safeguard way which create the fair but lost the efficiency. Especially in new agriculture insurance, there is a gap between pension replacement rate and actual demand. The article forecast the relationship through pension substitution rate of individual account with fund accumulation quantity, in addition with actuarial in pension standard to obtain the result of pay-as-you-go or full-funded system at present. Then the article draw into the concept of notional defined contribution model. At last through the analysis with other country which using the notional defined contribution model, which can get result that the notional defined contribution model has more advantage for China.
\end{abstract}

Keywords-all-inclusive society mode; pension substitution rate; notional defined contribution model

\section{RESEARCH BACKGROUND AND PROBLEM INTRODUCTION}

What China's social security concerns more is the assistance-centered policy. Zheng Gongcheng (2011) pointed out that the social welfare has been lagging behind the development of the social insurance and assistance from the perspective of social policy, and the reform and development strategy of China's social welfare should be the transformation of Chinese social welfare system from the care for the weak to the generalized welfare system for the whole people. In September 2009, the State Council released the Guidance on Implementation of the Pilot of New-type Rural Social Endowment Insurance, formally proposing the establishment of the new-type rural social endowment insurance system integrating individual payment, collective allowance and government subsidies. Up to 2011, the pilot of social endowment insurance for urban residents was implemented at the national level, which was another great strategy made by the State Council to speed up the coverage of the social security system followed by the new-type rural social endowment insurance. China's social security system is turning towards the generalized welfare society.

\section{A. Research Background}

There is a controversy among many scholars for the choice of current endowment insurance financing mode.
Yang Yansui mentioned (2010), due to insufficient funds, a large part of individual account payment was used to pay in the pay-as-you-go plan, and thus the problem of "empty account" emerges. The ultimate old-aged pension was granted according to the accounting amount. Because of the phenomenon of fund embezzlement, the individual accumulation account becomes a deformed mode of nominal account. Jiang Yan (2009) argued that, the original intention that China introduced the accumulative individual accounts is to strengthen the payment incentives and reduce the government's aging care burden. In contrast, as for the nominal account, it can be seen that some experts have different views. Yang Jianhai (2012) argued that the nominal account system did not have the decentralization of funds caused by the pooling account and individual account, and can alleviate the financing gap problem of the social security. Wang Yang (2012) proposed that the underdevelopment of the Chinese capital market and the lower management level of investment management institutions were two major reasons why the implementation of nominal account was approved in China.

Over the years, the funded account does not work wel.In this case, it is necessary to rethink the rationality of real account.

\section{B. Problem Introduction}

First of all, the social security system nationwide will inevitably bring about some new problems. By the end of 2011, nearly 290 million people covered the basic urban endowment insurance for enterprise employees, and 330 million people covered the new-type rural social endowment insurance, with addition with the number of people covering the endowment insurance for urban residents in 2012, it can be said that the coverage of endowment insurance was very impressive. But in the capital, the urban and new-type rural social endowment insurance is divided into two parts, i.e. individual account and basic old-aged pension. The fund of individual account comes from individual payment, collective allowance and local fiscal subsidies; the basic old-aged pension comes from the national finance and local finance (see Table 1). The proportion of individual payment is more than the premium-paid base of new-type rural social endowment insurance. 
TABLE I. CONTRAST TABLE OF CHINA's SOCIAL ENDOWMENT INSURANCE SYSTEM

\begin{tabular}{|c|c|c|c|c|c|}
\hline & $\begin{array}{c}\text { Insura } \\
\text { nce }\end{array}$ & $\begin{array}{c}\text { Payment } \\
\text { source }\end{array}$ & $\begin{array}{c}\text { Accou } \\
\text { nt }\end{array}$ & $\begin{array}{c}\text { Treatme } \\
\text { nt }\end{array}$ & \\
\hline \multirow[t]{4}{*}{$\begin{array}{l}\mathrm{Ur} \\
\mathrm{ba} \\
\mathrm{n}\end{array}$} & \multirow[t]{2}{*}{$\begin{array}{l}\text { Employ } \\
\text { ees }\end{array}$} & $\begin{array}{l}20 \% \text { of } \\
\text { enterprise total } \\
\text { Payroll }\end{array}$ & $\begin{array}{l}\text { Pooling } \\
\text { account }\end{array}$ & $\begin{array}{l}20 \% \text { of } \\
\text { average } \\
\text { wage }\end{array}$ & \multirow[t]{4}{*}{ High } \\
\hline & & $\begin{array}{l}8 \% \text { of } \\
\text { employees' } \\
\text { salaries }\end{array}$ & $\begin{array}{l}\text { Individ } \\
\text { ual } \\
\text { account }\end{array}$ & $\begin{array}{l}\text { individual } \\
\text { account / } \\
120\end{array}$ & \\
\hline & \multirow[t]{2}{*}{$\begin{array}{l}\text { Residen } \\
\text { ts }\end{array}$} & $\begin{array}{l}\text { Government } \\
\text { finance }\end{array}$ & $\begin{array}{l}\text { Pooling } \\
\text { account }\end{array}$ & 55 yuan & \\
\hline & & $\begin{array}{l}100-1000 \text { yuan } \\
\text { at your option }\end{array}$ & $\begin{array}{l}\text { Individ } \\
\text { ual } \\
\text { account }\end{array}$ & $\begin{array}{l}\text { individual } \\
\text { account / } \\
139\end{array}$ & \\
\hline \multirow[t]{2}{*}{$\begin{array}{l}\mathrm{Ru} \\
\mathrm{ral}\end{array}$} & \multirow{2}{*}{$\begin{array}{l}\text { New-ty } \\
\text { pe rural } \\
\text { social } \\
\text { endow } \\
\text { ment } \\
\text { insuran } \\
\text { ce }\end{array}$} & $\begin{array}{l}\text { Government } \\
\text { finance }\end{array}$ & $\begin{array}{l}\text { Pooling } \\
\text { account }\end{array}$ & 55 yuan & \multirow[t]{2}{*}{ Low } \\
\hline & & $\begin{array}{l}30 \text { yuan for the } \\
\text { government and } \\
\text { the collective, } \\
100-500 \text { yuan at } \\
\text { your option }\end{array}$ & $\begin{array}{l}\text { Individ } \\
\text { ual } \\
\text { account }\end{array}$ & $\begin{array}{l}\text { individual } \\
\text { account / } \\
139\end{array}$ & \\
\hline
\end{tabular}

Data source: obtained through the integration of Guidance on the Pilot of New-type Rural Endowment Insurance, urban payment and treatment.

China social endowment insurance system is the method to combine the pooling account with individual account, and its common ground is: the individual must pay the fees, and then obtain the corresponding treatment. Because of its low payment rate, the replacement rate of new-type rural social endowment insurance is much lower than the security level of the urban endowment insurance. Therefore, what we can see the urban and rural endowment insurance system is the fairness, but faced with the problem of financial pressure caused by the rapid aging of population, the application of nominal account system may have different effect on rural social endowment insurance.

\section{REDUCTION AND ANALYSIS OF OLD-AGED PENSION ON INDIVIDUAL ACCOUNT OF NEW-TYPE RURAL SOCIAL ENDOWMENT INSURANCE}

According to the suggestions by the World Bank, the multi-pillar endowment insurance system is composed of five pillars. In essence, the new-type rural social endowment insurance also belongs to the first-pillar-oriented system proposed by the World Bank. But whether the individual account can cover the three-pillar accumulation mode, i.e. social endowment insurance, supplementary endowment insurance and deposit endowment insurance, is in doubt. And is the nominal account financing mode in China a better choice relative to the current "pooling-individual account combination" ?

\section{A. Prediction of Replacement Rate of Old-aged Pension and Fund Accumulation Quantitative Relationship}

Before making an actuarial analysis of individual account of the new-type rural social endowment insurance, predict the transfer of endowment insurance fund under the condition of the accumulation system.

\section{Assuming that:}

The replacement rate of an economic entity is expressed by $\mathrm{m}$. The replacement rate refers to the proportion in which the retiree' $s$ pension accounts for on-the-job worker' $s$ wage. The proportion of employees in the total population is expressed by $\mathrm{n}$, and then the support rate, namely, the number of retirees per unit on-the-job personnel support, is expressed by $(1-n) / n$; then the total wages of employees is expressed by $\mathrm{p}$; the accumulative fund of endowment insurance implementing the endowment insurance system is expressed by q; the endowment insurance fund which is paid to the retirees is expressed by b. Since the ratio of quantity of the money the employees and the retirees account for in the economic entity respectively should be equal to that of their own quantity demanded for total social products, it can be obtained:

$$
\frac{\text { Currency }}{\text { Demand }}=\frac{p-b}{n}=\frac{q+b}{(1-n) m}
$$

According to the equation, the amount of endowment insurance fund in China can be calculated under the conditions of different replacement rates and support rates.

TABLE II. TABLE OF CALCULATION FOR THE AMOUNT OF ENDOWMENT INSURANCE FUND

\begin{tabular}{|c|c|c|c|c|c|c|}
\hline $\begin{array}{c}\text { Repl } \\
\text { acem } \\
\text { ent }\end{array}$ & $\begin{array}{c}\text { Suppo } \\
\text { rt }\end{array}$ & $q=0$ & $q=\frac{1}{8} p$ & $q=\frac{1}{4} p$ & $q=\frac{1}{2} p$ & $q=p$ \\
\hline $50 \%$ & $20 \%$ & $\frac{1}{11} p$ & $-\frac{1}{44} p$ & $-\frac{3}{22} p$ & $-\frac{4}{11} p$ & $-\frac{9}{11} p$ \\
\cline { 2 - 7 } & $50 \%$ & $\frac{1}{5} p$ & $\frac{1}{10} p$ & 0 & $-\frac{1}{5} p$ & $-\frac{3}{5} p$ \\
\hline $100 \%$ & $20 \%$ & $\frac{1}{6} p$ & $\frac{1}{16} p$ & $-\frac{1}{24} p$ & $-\frac{1}{4} p$ & $-\frac{2}{3} p$ \\
\hline & $50 \%$ & $\frac{1}{3} p$ & $\frac{1}{4} p$ & $\frac{1}{6} p$ & 0 & $-\frac{1}{3} p$ \\
\hline
\end{tabular}

Data results are the predictions of endowment insurance fund under the conditions of different replacement rates and support rates

It can be seen (Table 3) that there is a great difference among the endowment insurance funds raised through the pay-as-you-go and fully-funded system under the condition of different accumulation rates. With the rise of fund expenditures in the replacement rate and support rate, the reverse situation is very serious, thereby the effective distribution between the employees and the retirees is uneven, greatly threatening the aging care function of the endowment insurance system; however, in the case of low replacement rate and support rate, the pay-as-you-go system can reach a stable and appropriate effect.

\section{TABLE III. ANALYSIS OF PREDICTION RESUlTS}

\begin{tabular}{|c|l|l|}
\hline$q=0$ & $\begin{array}{l}\text { Old-age } \\
\mathrm{d} \\
\text { pension } \\
\text { financin } \\
\mathrm{g} \text { mode } \\
\text { in the } \\
\text { pay-as-y } \\
\text { ou-go } \\
\text { system }\end{array}$ & $\begin{array}{l}\text { With the increase of replacement rate and support } \\
\text { rate, the proportion in which the endowment } \\
\text { insurance premium (tax) accounts in the total } \\
\text { current income of the employees becomes higher. } \\
\text { (For example: when the replacement rate is } \\
100 \% \text { and the support rate is 50\%, the proportion } \\
\text { is 33.3\%; At this point, the government needs to } \\
\text { charge 33.3\% of the total income of the employees } \\
\text { to meet the aging-care needs of the retirees) }\end{array}$ \\
\hline$q=\frac{1}{8}$ & $\begin{array}{l}\text { Accumu } \\
\text { lative } \\
\text { financin } \\
\text { g mode } \\
\text { of the } \\
\text { insuranc } \\
\text { e }\end{array}$ & $\begin{array}{l}\text { 1) As the scale of endowment insurance fund } \\
\text { changes, the transfer direction and amount } \\
\text { changes accordingly } \\
2 \text { ) The higher the proportion in which the } \\
\text { endowment insurance fund accounts for in the } \\
\text { total current income of employees is, the lower the } \\
\text { scale required by the government to charge the } \\
\text { endowment insurance fund is }\end{array}$ \\
\hline
\end{tabular}




\section{B. the actuary of NREIS Individual Account pension}

\section{1) The basic assumptions of the model}

Through the previous estimates, we got the different results of high substitution rate and low replacement rate of two kinds of system modes. Then through the research of NREIS individual account pension in different payment period and different insurance lines to analyze its replacement rate, the rate of support, finally determine whether the PAYG system or fund accumulation system is more suitable for low replacement rate, the rate of support.

According to clearly rules of the "guidance", to determine the individual payment standard and payment age, and make 5 years as a unit to a classified here.

TABLE IV. INDIVIDUAL PAYMENT AND PAYMENT AGE

\begin{tabular}{|l|l|l|l|l|l|}
\hline $\begin{array}{c}\text { Individual } \\
\text { payment } \\
\text { amount }\end{array}$ & $\begin{array}{c}\mathbf{1 0 0 y} \\
\text { uan }\end{array}$ & $\begin{array}{c}\mathbf{2 0 0 y} \\
\text { uan }\end{array}$ & $\begin{array}{c}\text { 300y } \\
\text { uan }\end{array}$ & $\begin{array}{c}\text { 400y } \\
\text { uan }\end{array}$ & $\begin{array}{c}\text { 500y } \\
\text { uan }\end{array}$ \\
\hline $\begin{array}{l}\text { Payment } \\
\text { age }\end{array}$ & 16 & 20 & 25 & 30 & 35 \\
\cline { 2 - 6 } & 40 & 45 & 50 & 55 & 60 \\
\hline
\end{tabular}

Data hypothesis: keep continuous payment without interruption, and do not consider the

\section{2) Establishment of model} problem of surrender.

Hypothesis: $\mathrm{Y}$ is for the insured farmers began to pay for the personal account pension age; $\mathrm{R}$ is for annual interest rate of accumulation fund of individual account pension; D1 is for the payment amount of individual per year; D2 is for the payment amount of individual account which is from government subsidies; $u$ is the monthly payment of personal account pension; $\mathrm{W}$ is for the per capita net income of rural residents a year before benefit period; W0 is as the per capita net income of rural residents a year before payment period; $\mathrm{k}$ is for the annual growth rate of per capita net income of rural residents; $\mathrm{m}$ is for the receive time limit of individual pension account for the insured farmers; $i$ is for the interest rate of benefit period.

a) The accumulated total amount of payment amount each year $(60$ years old is the payment period early years):The accumulated amount from the early year of payment period to the early year of benefit period :

$$
X_{1}=\left(D_{1}+D_{2}\right)(1+r)^{60-y}
$$

The accumulated amount from the last year of payment period to the early year of benefit period:

$$
X_{y}=\left(D_{1}+D_{2}\right)(1+r)
$$

When the insured farmers begin to receive the pension, the fund accumulation account of the individual account $\mathrm{M}$ is for:

$$
M=\left(D_{1}+D_{2}\right) \sum_{i=1}^{60-y}(1+r)^{60-y+1-i}
$$

b) The payment value of individual account pension each year is :The pension payment amount in the first year of benefit period is at the present value of :

$$
12 u(1+i)
$$

In the $\mathrm{m}$ year of payment period, the cash of pension payment amount at the beginning of the period is :

$$
12 u(1+i)^{m-1}
$$

When the farmer insured at the age of $y$,the total value he receive at the age of 60 is :

$$
N=12 u \sum_{j=0}^{m-1}(1+i)^{j}
$$

c) Then we can know the substitution rate is:

$$
P=\frac{M}{N}=\frac{\left(D_{1}+D_{2}\right) \sum_{i=1}^{60-y}(1+r)^{60-y+1-i}}{12 \sum_{j=0}^{m-1}(1+i)^{j}}
$$

\begin{tabular}{|c|c|c|c|c|c|c|}
\hline \multirow{3}{*}{$\begin{array}{c}\text { Insu } \\
\text { red } \\
\text { age }\end{array}$} & \multicolumn{6}{|c|}{ Pay grade } \\
\hline & \multicolumn{2}{|c|}{100 yuan } & \multicolumn{2}{|c|}{300 yuan } & \multicolumn{2}{|c|}{ 500yuan } \\
\hline & $\begin{array}{c}\text { Pensi } \\
\text { on } \\
\text { paym } \\
\text { ent }\end{array}$ & $\begin{array}{c}\text { Subs } \\
\text { tituti } \\
\text { on } \\
\text { rate }\end{array}$ & $\begin{array}{c}\text { Pensi } \\
\text { on } \\
\text { paym } \\
\text { ent }\end{array}$ & $\begin{array}{c}\text { Sub } \\
\text { stitu } \\
\text { tion } \\
\text { rate }\end{array}$ & $\begin{array}{c}\text { Pensio } \\
\text { n } \\
\text { payme } \\
\text { nt }\end{array}$ & $\begin{array}{c}\text { Subst } \\
\text { itutio } \\
\mathbf{n} \\
\text { rate }\end{array}$ \\
\hline 16 & 76.83 & 2.89 & 195.03 & 7.36 & 313.23 & 11.80 \\
\hline 20 & 66.35 & 2.97 & 168.43 & 7.54 & 270.50 & 12.11 \\
\hline 25 & 54.50 & 3.03 & 138.34 & 7.69 & 222.18 & 12.35 \\
\hline 30 & 43.89 & 3.03 & 111.42 & 7.69 & 178.94 & 12.35 \\
\hline 35 & 34.40 & 2.95 & 87.33 & 7.48 & 140.26 & 12.02 \\
\hline 40 & 25.91 & 2.76 & 65.78 & 7.00 & 105.64 & 11.23 \\
\hline 45 & 18.32 & 2.42 & 46.50 & 6.14 & 74.68 & 9.86 \\
\hline 50 & 11.52 & 1.89 & 29.25 & 4.79 & 46.97 & 7.70 \\
\hline 55 & 5.44 & 1.11 & 13.81 & 2.81 & 22.18 & 4.51 \\
\hline 59 & 1.04 & 0.25 & 2.64 & 0.64 & 4.24 & 1.03 \\
\hline
\end{tabular}

According to the actuarial results of substitution rate (in table 6):

TABLE V. INDIVIDUAL ACCOUNT PENSION LEVEL AND THE ACTUARIAL RESULTS OF SUBSTITUTION RATE

Data sources: according to the payment level, through the calculation formula of substitution rate the

The substitution rate of individual account pension is low, the highest rate of substitution (if you insure at age of 16 ,choose the highest level of 500 yuan and pay for 44 years) is only $11.5 \%$,it is far lower than urban workers with combination of social pooling and individual account of $30 \%$ substitution rate.

\section{3) Comparative analysis}

Combined with predicted and actuarial results we can see that the fixed payment is lack of flexibility, low level of farmer income, the limited pension substitution rate, under the fund accumulation, the income of low income group has had the opposite effect and increase the financial burden of the government. Endowment insurance is a long-term payment system model, knowing that there are differences between rural and urban and sharing the same kinds of policies, this is a question.

Endowment insurance system is a kind of rigid demand, High pension benefits and the job income is also high. But the high income group have strong self protection itself, they can receive a high level of retirement pension after retire, the low income group have week self protection, the retirement pension benefits cannot be guaranteed after retire. This is maximum lack of efficiency with fair premise. 


\section{APPLICATION OF NOMINAL ACCOUNT SYSTEM}

\section{A. Sweden}

Sweden is the first country to use the nominal account system, as origination country of nominal account system; on the whole, Sweden's pension system reforms have been successful. Since the 80's of last century, traditional Swedish pension began to arise crisis; therefore, the nominal account was added into the public pension system in legal in 1988.

TABLE VI. THE PENSION SYSTEM OF SWEDEN

\begin{tabular}{|l|l|l|l|}
\hline & $\begin{array}{c}\text { Financing } \\
\text { method }\end{array}$ & $\begin{array}{c}\text { Contributio } \\
\text { n rates }\end{array}$ & $\begin{array}{c}\text { Salary } \\
\text { structure }\end{array}$ \\
\hline $\begin{array}{l}\text { Guaranteed } \\
\text { pension }\end{array}$ & PAYG & $\begin{array}{l}\text { The general } \\
\text { tax-financed }\end{array}$ & $\begin{array}{l}\text { Quota,house } \\
\text { hold survey }\end{array}$ \\
\hline Nominal account & PAYG & $16 \%$ & DC \\
\hline $\begin{array}{l}\text { Account } \\
\text { accumulated }\end{array}$ & Total & $2.5 \%$ & DC \\
\hline
\end{tabular}

Data source: arranged from Swedish pension system of "nominal account state"

In the new Swedish pension system, both the nominal account and accumulated system are DC type salary structure. the nominal account pension set up on the basis of individual account, the total payment of employer and employee is $18.5 \%$ salary, $16 \%$ of it will divide into the nominal account.

We can calculated their pension level of treatment and the figure of substitution date per month when they retired at the age of 65 , seen in the image below.

TABLE VII. INDIVIDUAL RETIREMENT BENEFITS AND SUBSTITUTION RATE

\begin{tabular}{|l|l|l|l|}
\hline $\begin{array}{c}\text { Year of } \\
\text { birth }\end{array}$ & $\begin{array}{c}\text { Retirement } \\
\text { pension at age 65 }\end{array}$ & $\begin{array}{c}\text { Average } \\
\text { income }\end{array}$ & $\begin{array}{c}\text { Substitution } \\
\text { rate(\%) }\end{array}$ \\
\hline 1942 & 11400 & 17500 & 65 \\
\hline 1965 & 14900 & 26300 & 57 \\
\hline 1990 & 21800 & 40900 & 53 \\
\hline
\end{tabular}

Data sources: it is got by the calculation of individual retirement pension.

From the table above, we can know that after adding the new system, the treatment of pension declined, but the substitution rate of pension remained at a relatively high level, the most important is that this can make up for the traditional ATP system which has high payment and brings financial pressure to the government.

\section{B. Korea}

As the East Asian country, Korea faced many problems which are similar with China. In 2007, Korea introduced a non contributory basic pension, but the sustainability of finance faced a challenge. It can be said that China and Korea's pension system faces the same pressure of financial and aging of population.

Since 1960, the old at the age of 65 or more has a rising proportion state all over the world. In 2004, the population aged over 65 years old have a respectively proportion of $9.0 \%$ and $7.5 \%$ in the two country. At that time, the elderly dependency rate index of China and Korea will rise to 0.37 and 0.25 , and these are close to or exceed the level of OECD.( in Table 9)
TABLE VIII. THE DEVELOPMENT TREND OF AGING POPULATION

\begin{tabular}{|l|l|l|l|l|l|l|}
\hline & $\begin{array}{l}\text { over } \\
\mathbf{6 5} \\
\text { in } \\
\mathbf{1 9 6 0}\end{array}$ & $\begin{array}{l}\text { over } \\
\mathbf{6 5} \\
\text { in }\end{array}$ & $\begin{array}{l}\text { over } \\
\mathbf{6 5} \text { in } \\
\mathbf{2 0 3 0}\end{array}$ & $\begin{array}{l}\text { depend } \\
\text { ency } \\
\text { rate in } \\
\mathbf{1 9 6 0}\end{array}$ & $\begin{array}{l}\text { depend } \\
\text { ency } \\
\text { rate in } \\
\mathbf{2 0 0 4}\end{array}$ & $\begin{array}{l}\text { depend } \\
\text { ency } \\
\text { rate in } \\
\mathbf{2 0 3 0}\end{array}$ \\
\hline OECD & 9.4 & 15.0 & 22.7 & 0.15 & 0.22 & 0.37 \\
Non & 4.2 & 6.1 & 10.9 & 0.08 & 0.10 & 0.17 \\
OECD & 3.3 & 9.0 & 23.9 & 0.06 & 0.13 & 0.37 \\
Korea & 4.8 & 7.5 & 16.4 & 0.09 & 0.11 & 0.25 \\
China & & & & & & \\
\hline
\end{tabular}

Data sources: "investigation and study of aging in East Asia, Europe"

\section{THOUGHTS AND SUGGESTIONS}

Problems of Endowment insurance policy in the way of innovation and reform, will be gradually highlighted, because the gap between urban and rural areas is the fact that does not dispute. In the policy of uniformity ,to solve explores the favorable policy for the vulnerable groups, how to narrow the difference is the first condition of reform, it is not only from the policy, from the form to fairness, but also to create a better space for the old age in the rural.

China lack of the market conditions to instigate the fund individual account. But nominal account system not only to a certain extent to lighten the burden of government, investment bottlenecks of the individual account fund can be avoided the pooling account or the individual account, it can alleviate the gap funds, we cannot simply copy under existing conditions, we can find useful ideas from the new agricultural insurance.

The use of nominal account system in the new agricultural insurance is to protect the vulnerable social groups. Compared with the PAYG system, it has strong ability to resist risks; Sweden succeeded for it didn't need a mature capital market, low transition cost, it can be used as an important transition system of long-term reform in the future. For the countries such as China, the background of large population of peasant has vast importance.

\section{REFERENCE}

[1] Pang Fengxi. Nominal Account System: Reasonable Choice of China's Endowment Insurance Mode -- Based on Comparing the Difference between the Pay as You Go System and Fully Accumulated System [J]. Economic System and Policy, 2012.

[2] Long Chaoyang. China's Old-age Insurance System Reform: Fund Accumulation or Nominal Account System [J]. South of the Five Ridges College of Zhongshan University, 2011.

[3] Zhang Hanyue. Nominal Account System --Practicable Options of Chinese Endowment Insurance System Reform [J]. Public Management School of Sichuan University, 2010.

[4] Zheng Wei. Nominal Account System and Pension System Reform in China: Path Choice and Challenge [J]. Xi' an: Northeast Normal University, 2010.

[5] Feng Wanli.Suitability Analysis of Nominal Account System in China [J]. Academic Discussion, 2010.

[6] Weng Renmu. Reason Analysis of Basic Endowment Insurance of Chinese Enterprises Not Adopting the Nominal Account System [J]. Employment Security.2010.

[7] Zeng Jin. Study of Basic Old-age Insurance Mode -- Based on the Transfer of Nominal Account System Design [J]. Fujian : Fujian Normal University, 2010. 